\title{
A Credit Score System for Socially Responsible Lending
}

Begoña Gutiérrez-Nieto 1 ,*

Email bgn@unizar.es

Carlos Serrano-Cinca 1

Juan Camón-Cala 1

1 Department of Accounting and Finance, Universidad de Zaragoza, Saragossa, Spain

\section{Abstract}

Ethical banking, microfinance institutions or certain credit cooperatives, among others, grant socially responsible loans. This paper presents a credit score system for them. The model evaluates social and financial aspects of the borrower. The financial aspects are evaluated under the conventional banking framework, by analysing accounting statements and financial projections. The social aspects try to quantify the loan impact on the achievement of millennium development goalsMillennium Development Goals such as employment, education, environment, health or community impact. The social credit score model should incorporate the lender's know-how and should also be coherent with its mission. This is done using multi-criteria decision makingMulti-Criteria Decision Making (MCDM). The paper illustrates a real case: a loan application by a social entrepreneur presented to a socially responsible lender. The decision support system not only produces a score, but also reveals strengths and weaknesses of the application.

AQ1

Keywords

Ethical banking

Social impact assessment 


\section{Credit scoring}

Multi-criteria decision makingMulti-Criteria Decision Making (MCDM)

Financial ratios

\section{Introduction}

Financial institutions use credit scoring to distinguish among good and bad borrowers. For the majority of these entities, a good borrower is simply the one who pays back his loans. However, for social banks, good borrowers are those that, furthermore, perform activities with a social impact; they do good in the ethical sense of the word. Consequently, there is a growing interest in incorporating social issues into credit score systems. Beyond assessing the non-payment probability, these systems should incorporate both the social commitment of the applicant and the social impact of the project to be financed. This paper presents a credit score model that incorporates social and financial variables. Financial variables are those commonly used by banks. Social variables are not yet standardized, but are currently being researched (Vanclay 2010; IAIA 2011; GRI 2011; Searcy 2012).

AQ2

There are different kinds of social financial institutions. This paper focuses on socially responsible lenders, which give loans to socially orientated projects. One example is ethical banks, which offer social returns, as well as financial returns, to their depositors. Another example is Community Development Financial Institutions (CDFI), aimed at financially excluded enterprises; see Appleyard (2011). Microfinance Institutions (MFIs) give loans to the poorest, Morduch (1999). Financial cooperative structures also have a social aim, an example of which are the Rotating Savings and Credit Associations (ROSCA), informal savings and loan schemes, frequent in developing countries, studied by Ambec and Treich (2007). Social Venture Capital institutions (SVC) invest in social entrepreneurs. Harris et al. (2009) suggest that social entrepreneurship can include business ventures with a strong social purpose, but also hybrid organizations that mix both non-profit and for-profit elements.

This paper proposes that loan applications presented to these kinds of entities be assessed from a financial and a social point of view. Being financial institutions, they should apply a scoring mechanism, in line with Basel Accords (BIS 2004). 
But this credit scoring has to be different from the one applied by a mainstream bank, for which only repayment matters. Social lenders should examine the social and ethical side of the applicant project such as: how many jobs are to be created, especially for disadvantaged workers? Or what is the intended impact in the community, or in the environment?

The proposed decision-making model incorporates social issues, weighing them with financial issues for decision making by socially responsible lenders. These institutions have different missions; for example, some prioritize the environment, whereas others prioritize women empowerment. The model incorporates the importance of each aspect in a way that is coherent with the institutional mission. This can be done by means of Multi-criteria decision makingMulti-Criteria Decision Making (MCDM). There are several papers using MCDM in business ethics, such as Millet (1998), Ruf et al. (1998), or Stein and Ahmad (2009).

The model assesses the credit history of the applicant (past), accounting information and intangible assets from the applicant itself (present), and the project to be financed, from the financial and social points of view (future). These criteria are reflected in different measurable indicators, which are evaluated by credit analysts. Beyond a score, the model allows identifying the strengths and weaknesses of the project to be financed.

The most challenging aspect of the model is how to value social impacts related to organizational aims (Forbes 1998; Frame and O’Connor 2011). Among all the different available approaches, the Social Return on Investment (SROI) by REDF (2001) has been chosen. SROI tries to transform social aims into financial measures using proxies. This case is especially useful for scoring purposes. In our approach, SROI results are weighed with the preferences matrix obtained through MCDM.

The model has been tested on a real case: a loan application by a bike courier company presented to a Spanish financial services cooperative. This cooperative has limited resources and has to prioritize those applications that, being financially sustainable, have a high social impact. This justifies the need for a social credit scoring methodology.

The rest of the paper is structured as follows: “Socially Responsible Lenders and 
Social Impact Assessment" section presents a discussion on socially responsible lenders, their credit scoring systems, and the different methodologies used for social impact valuation. "Modelling the Credit Scoring Decisional Process” section presents the social credit scoring model. "Assessment of the Loan Application Presented by the Bike Courier Company" section illustrates the real loan application and its assessment. The final section discusses the conclusions.

\section{Socially Responsible Lenders and Social Impact Assessment}

\section{Entities that Finance Social Projects}

There is a wide range of entities that fund social projects. Different criteria can be applied to establish a classification: the type of institution, its mission, the way the institution is funded and the kind of financial instrument intermediated. This way, five categories are found: (1) ethical banks, (2) financial entities with a social mission, (3) revolving loan and savings funds structures, (4) social entities that do not collect savings and (5) conventional banks that offer loans for social purposes. Table 1 presents these categories, with a brief explanation of their concept and of the way they assess loan applications.

\section{Table 1}

Entities that finance social projects

\begin{tabular}{|l|l|}
$\begin{array}{l}\text { Socially } \\
\text { responsible } \\
\text { lenders }\end{array}$ & Concept \\
\hline Ethical banks & $\begin{array}{l}\text { Financial institutions that only } \\
\text { fund target groups or causes, } \\
\text { generally social and/or } \\
\text { environmentally orientated }\end{array}$ \\
\hline
\end{tabular}

Financial entities with a social mission

Revolving loan and savings funds structures
Financial entities with a social mission: members' self-help, or a percentage of profits allocated to charities. They grant social and conventional loans

Social institutions with a social mission, generally members' self-help. They collect savings from its members and only grant

\section{Credit score}

Purely financial score. Previously, they apply a negative filter to avoid projects with a negative impact on social or environmental issues

Purely financial score. Sometimes they apply a positive screen to finance socially oriented projects

A commission representing its members assesses loan's applications. To meet some social criteria it can be 


\begin{tabular}{l|l|l|}
$\begin{array}{l}\text { Socially } \\
\text { responsible } \\
\text { lenders }\end{array}$ & Concept & Credit score \\
\hline & loans to them & $\begin{array}{l}\text { compulsory to become a } \\
\text { member and apply for a loan }\end{array}$ \\
\hline $\begin{array}{l}\text { Social entities } \\
\text { that do not } \\
\text { collect savings }\end{array}$ & $\begin{array}{l}\text { Social institutions that only fund } \\
\text { target groups or causes, generally } \\
\text { social and/or environmentally } \\
\text { orientated. They do not collect } \\
\text { savings. Examples are non-profit } \\
\text { Microfinance Institutions and } \\
\text { Community Development }\end{array}$ & $\begin{array}{l}\text { Sometimes the score does not } \\
\text { exist: the applicant or } \\
\text { business just needs to belong } \\
\text { to the target group. For } \\
\text { example, poverty scorecards } \\
\text { to assess the poverty level of } \\
\text { the applicant before asking } \\
\text { for a loan }\end{array}$ \\
\hline $\begin{array}{l}\text { Financial Institutions } \\
\text { bonventional } \\
\text { banks that offer } \\
\text { purpos social }\end{array}$ & $\begin{array}{l}\text { Conventional financial institutions } \\
\text { that offer social and conventional } \\
\text { financial products. The social } \\
\text { issue is a small niche market for } \\
\text { them }\end{array}$ & $\begin{array}{l}\text { Conventional financial score, } \\
\text { based on expert systems or } \\
\text { multivariate mathematical } \\
\text { models }\end{array}$ \\
\hline & &
\end{tabular}

\section{Ethical Banks}

These banks are a special kind of banks whose depositors acknowledge that their savings will fund target groups focused on social or environmental issues (Buttle 2007). The most widespread ethical bank is Triodos Bank, a European-based bank, with 363,086 accounts and 21,900 loans in 2011. Triodos Bank first applies a negative filter to its credit applications, rejecting sectors such as tobacco or gambling, and then it uses a traditional credit scoring (Triodos Bank 2011).

\section{Financial Entities with a Social Mission}

A well-known example is credit unions, which are self-help, cooperative financial institutions. Anyone can become a member of a credit union within the accepted common bond of association, and its members can make use of its services, accepting the corresponding responsibilities (Goddard et al. 2002). Many savings banks also belong to this category, providing community outreach and supporting charitable and cultural activities. They do not generally perform socially responsible lending, but some of their lending activities are intended for disadvantaged groups. Most of their loans are evaluated under financial criteria, applying a filter when the loan is socially oriented.

\section{Revolving Loan and Savings Funds Structures}


These entities are not pure financial institutions. They are socially rooted initiatives that collect informal savings from individuals or companies under revolving loan and savings funds structures. An example is financial services cooperatives, whose members have to meet certain ethical standards. Members deposit their savings in the cooperative, which gives them the right to apply for loans. Credit applications are evaluated by a commission of experts that represents cooperative members. They analyse the financial needs of the applicant, and the social aspects of the application, trying to find the most suitable financial solution for the member and for the cooperative. A similar idea lies behind the Rotating Savings and Credit Associations (ROSCA) structures in developing countries; see Ambec and Treich (2007). A ROSCA collects its members' savings and redistributes them in a rotary way among all the members. Every member receives his loan and the ROSCA ends. These loans are approved by a commission or by all the ROSCA members (Bouman 1995).

\section{Social Entities that Do Not Collect Savings}

These are non-banking institutions funded by loans or grants. These funds are channelled to loans for individuals or companies excluded from the financial circuit. These include non-profit Microfinance Institutions (MFIs). According to Schreiner (2002), in MFIs, the conventional credit scoring complements but does not substitute for the personal evaluation by loan officers. Community Development Financial Institutions (CDFI) also belong to this category. CDFIs obtain grants and philanthropic investment and give loans to social enterprises (Appleyard 2011).

\section{Conventional Banks that Offer Loans for Social Purposes}

Social issues attract clients in conventional banks. Because of this interest from clients, conventional banks offer such products as socially responsible credit cards or charitable savings accounts (Fock et al. 2011). They also give loans, as for example USA banks under the 1977 Community Reinvestment Act, which requires depository institutions to take affirmative actions to meet the credit needs of their communities, including low-income neighbourhoods (Johnson and Sarkar 1996). Financial institutions have developed, from clients' past behaviour databases, a good number of credit scoring systems, applying statistical models or expert systems. They do not usually analyse the social impact of the loan. Although they are not lenders, ethical mutual funds and social venture capital 
institutions (SVC) invest in socially driven companies, and they are deeply interested in the social valuation of the applicant. As for social venture capital, its origins go back to social entrepreneurs, which focus on creating social value. There are many kinds of social entrepreneurship, from philanthropists to social business angels or financial services cooperatives. Zahra et al. (2009) identify three types of social entrepreneurs: Social Bricoleur, Social Constructionist and Social Engineer.

\section{Social Impact Assessment}

The most complex part of a social credit score is social impact assessment (SIA). According to Burdge (2003), there is minimal consensus as to the definition for SIA. Becker (2001), for example, defines SIA as the process of identifying the future consequences of a current or proposed action, which are related to individuals, organizations and social macro-systems.

Different social reporting standards emerge from SIA. The triple bottom line provides a framework for measuring and reporting corporate performance using economic, social and environmental parameters, Elkington (1997). The global reporting initiative (GRI) constitutes the world's most widely used sustainability reporting framework and follows the Triple Bottom Line approach (GRI 2011). GRI is used by organizations of any size, sector or location but allows excessive arbitrariness (Moneva et al. 2006). There is no ISO standard for social impact assessment. Tsai and Chou (2009) propose four different management standards for companies to obtain sustainable competitive advantages.

A different approach to measuring social impact is the social return on investment (SROI). It was first developed by the Roberts Enterprise Development Fund with the aim of assessing the economic value of the job creation by its services programmes in San Francisco, REDF (2001). This approach is based on cost-benefit analysis and tries to transform social aims into financial measures using proxies. For example, if a social project is hiring homeless individuals, one of the proxies would assess the annual savings in homeless benefits.

Gutiérrez-Nieto et al. (2009) present a revision of the main social assessment methodologies in the microcredit field. The consultative group to assist the poorest (CGAP), an independent policy and research centre on microcredit, 
analyse different research methods used for data gathering and analysis to detect changes in client lives from microfinance programmes, CGAP (2011). The result of this kind of assessment could be incorporated in social credit scoring systems, as is done in this paper.

\section{Modelling the Credit Scoring Decisional Process}

This section illustrates a real case of social lending and how a credit score was obtained. It is a loan application presented to a Spanish financial services cooperative, Coop57. The research team asked Coop57 managers for real case data to develop and test a social credit score methodology. The applicant was a bike courier company, La Veloz. Both the funder and the applicant enjoy high standards of commitment towards society. They were pleased to collaborate with the research team in publishing their case, which could help other entities looking for references in social credit scoring.

Coop57 is a social entity that intermediates savings, but it is not supervised by the Spanish Central Bank. It is a revolving loan and savings fund structure, built on savings from members, which are social enterprises. These enterprises fund the cooperative, and when they have financial needs, they may ask the cooperative for a loan. When the 2009 financial crisis hit Spain, companies had difficulties accessing bank loans. Cooperative members' financial needs are now higher, so it is necessary to prioritize among loan applications. These applications are assessed separately by a financial and by a social committee.

The credit score decision system has been modelled with MCDM methods. There are several MCDM methods, among them, the most widely known are multipleattribute utility theory Multiple-Attribute Utility Theory(MAUT), multipleattribute value theoryMultiple-Attribute Value Theory (MAVT) and analytic hierarchy processAnalytic Hierarchy Process (AHP). MAUT can be considered as the leading paradigm for normative decision theory (Keeney and Raiffa 1976), but AHP was the methodology implemented. AHP algorithm was available in a spreadsheet, and Coop57 analysts found it very adequate to merge in the spreadsheet both financial ratios and social indicators. The Technology Acceptance Model (Davis 1989) argues that the perceived ease-of-use is a key fact in technology adoption, and in our case this was the main reason for AHP choice. 
Analytic Hierarchy Process (AHP) is a technique that simplifies a multifaceted problem by means of hierarchical analysis methodology, Saaty (1980) and Saaty (2013). AHP allows incorporating the knowledge of specialists in different fields within an expert system and enables subjective judgments between different criteria. AHP has been applied in social issues to aggregate measures of corporate social performance; see Ruf et al. (1998) and Millet (1998). But AHP is controversial in the field of decision analysis, because of its potential shortcomings, which are well documented in the mainstream literature, see Dyer (1990), Smith and von Winterfeldt (2004) or Peters and Zelewski (2008). One of them is the rank reversal problem, meaning changes in the ranks of the alternatives, as highlighted by Belton and Gear (1983). But AHP has two modes: relative measurement model and absolute measurement model. In the relative measurement model each alternative is compared with many other alternatives, using pairwise comparison. In the absolute measurement model (or rating method), a number of absolute levels of performance on each criterion are defined. This is the mode used in this paper. When using the absolute measurement model, the rankings are not affected by the addition or deletion of new loan applications. If many cooperative members apply for a loan simultaneously, the high number of alternatives would make it unviable the use of pairwise comparisons. For this reason, when financial institutions use AHP for loan granting, absolute measurement is the mode chosen, see Yurdakul and Iç (2004).

AHP, as a tool to build expert systems, allows the incorporation of the knowledge of human specialists in a given subject into computer software. Experts in accounting statements analysis, in financial projections and in social impact assessment collaborated in the building of the model. Although there is commercial software that performs AHP, the research team decided to build a tailored spreadsheet-based information system. This decision allowed the calculation of financial ratios or discounted cash flows and provided the matrix calculus needed by AHP. The spreadsheet has four main tabs, representing each of the AHP stages: (1) modelling, (2) prioritization, (3) assessment and (4) synthesis (Saaty 1980). Figure 1 shows the credit score process developed.

Fig. 1

Flowchart of the social credit scoring decisional process 


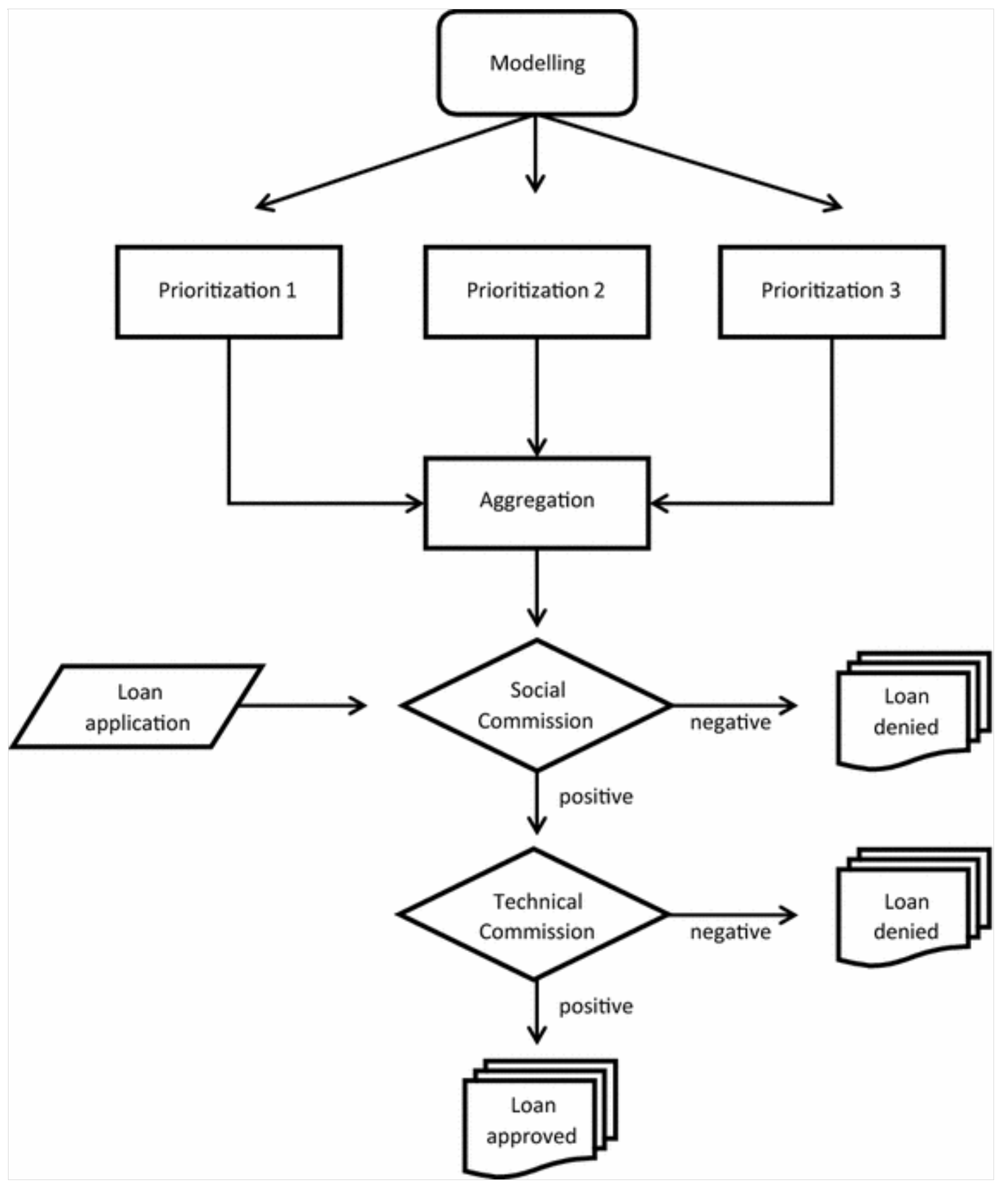

\section{Modelling}

This first stage built the model to represent the decisional process and selected the criteria to be assessed. This model was based on the credit application form used by the social committee and the financial committee of the cooperative. The proposed model was tested and improved by the cooperative's board of directors. The model has three main branches: history (past), company (present) and the project to be financed (future). Each branch has several criteria and each criterion has a set of associated indicators. Criteria are constructs (latent 
variables) that cannot be directly measured. To enable the assessment of each criterion, a series of indicators reflecting the criterion were selected. These indicators are proxy variables, which are measurable. For example, some indicators associated to the "innovation" criterion are the number of patents or the number of $\mathrm{R}+\mathrm{D}$ projects. Table 2 shows the three main branches, the 26 criteria, and a selection of the associated indicators.

\section{Table 2}

The model: branches, criteria and examples of indicators

\begin{tabular}{|c|c|c|c|c|}
\hline Branch & \multicolumn{3}{|l|}{ Criterion } & Indicators examples \\
\hline \multirow{3}{*}{ History } & & & $\begin{array}{l}\text { 1. History with } \\
\text { our company }\end{array}$ & $\begin{array}{l}\text { Payment delays, overdue debts } \\
\text { or lawsuits from internal } \\
\text { records on past relationship } \\
\text { with the applicant }\end{array}$ \\
\hline & & & $\begin{array}{l}\text { 2. History with } \\
\text { financial } \\
\text { institutions and } \\
\text { public sector }\end{array}$ & $\begin{array}{l}\text { Risk public data from } \\
\text { companies that assess } \\
\text { creditworthiness }\end{array}$ \\
\hline & & & $\begin{array}{l}\text { 3. History with } \\
\text { suppliers and } \\
\text { costumers }\end{array}$ & $\begin{array}{l}\text { Overdue or unpaid trade bills } \\
\text { from customers and suppliers }\end{array}$ \\
\hline \multirow{7}{*}{$\begin{array}{l}\text { The } \\
\text { company }\end{array}$} & \multirow{4}{*}{\multicolumn{2}{|c|}{$\begin{array}{l}\text { Accounting } \\
\text { information }\end{array}$}} & $\begin{array}{l}\text { 4. Business } \\
\text { growth }\end{array}$ & $\begin{array}{l}\text { Financial ratios such as } \\
\text { turnover growth or profits } \\
\text { growth }\end{array}$ \\
\hline & & & $\begin{array}{l}\text { 5. Profitability, } \\
\text { efficiency and } \\
\text { productivity }\end{array}$ & $\begin{array}{l}\text { Financial ratios such as staff } \\
\text { productivity and efficiency } \\
\text { ratios, ROE or ROA }\end{array}$ \\
\hline & & & $\begin{array}{l}\text { 6. Short-Term } \\
\text { Liquidity }\end{array}$ & $\begin{array}{l}\text { Financial ratios such as } \\
\text { working capital or quick ratio }\end{array}$ \\
\hline & & & $\begin{array}{l}\text { 7. Long-Term } \\
\text { Solvency }\end{array}$ & $\begin{array}{l}\text { Financial ratios such as } \\
\text { financial expense coverage } \\
\text { ratios, debt or solvency ratios }\end{array}$ \\
\hline & \multirow{3}{*}{ Intangibles } & \multirow{3}{*}{$\begin{array}{l}\text { Human } \\
\text { capital }\end{array}$} & $\begin{array}{l}\text { 8. Management } \\
\text { board }\end{array}$ & $\begin{array}{l}\text { Leadership and management } \\
\text { skills of the management } \\
\text { board, such as awards } \\
\text { received, years of experience } \\
\text { or educational levels }\end{array}$ \\
\hline & & & 9. Staff & $\begin{array}{l}\text { Attitude, knowledge, and } \\
\text { motivation skills of the staff }\end{array}$ \\
\hline & & & $\begin{array}{l}\text { 10. Labour } \\
\text { responsibility }\end{array}$ & $\begin{array}{l}\text { Items measuring the quality of } \\
\text { the relationships between the }\end{array}$ \\
\hline
\end{tabular}




\begin{tabular}{|c|c|c|c|}
\hline \multirow[t]{9}{*}{ Branch } & \multirow[t]{5}{*}{ Criterion } & & Indicators examples \\
\hline & & & company and its employees \\
\hline & & $\begin{array}{l}11 . \text { Vision and } \\
\text { values }\end{array}$ & $\begin{array}{l}\text { Items measuring the coherence } \\
\text { between vision and values and } \\
\text { the activity of the company }\end{array}$ \\
\hline & & $\begin{array}{l}\text { 12. Processes } \\
\text { and technology }\end{array}$ & $\begin{array}{l}\text { Use of adequate processes and } \\
\text { technology such as intranet, } \\
\text { e-commerce, or cash flow } \\
\text { budgets }\end{array}$ \\
\hline & & 13. Innovation & $\begin{array}{l}\text { Innovation levels, measured by } \\
\text { the number of } \mathrm{R}+\mathrm{D} \text { projects } \\
\text { financed or the number of } \\
\text { registered patents }\end{array}$ \\
\hline & \multirow{4}{*}{$\begin{array}{l}\text { External } \\
\text { capital }\end{array}$} & 14. Customers & $\begin{array}{l}\text { Value of the applicant's } \\
\text { customers, measured by the } \\
\text { length of customer } \\
\text { relationships or the complaint } \\
\text { ratio }\end{array}$ \\
\hline & & $\begin{array}{l}\text { 15. Social } \\
\text { Image of the } \\
\text { company }\end{array}$ & $\begin{array}{l}\text { Presence in the mass media, } \\
\text { awards and recognitions or } \\
\text { web page popularity }\end{array}$ \\
\hline & & 16. Networks & $\begin{array}{l}\text { Presence in social and } \\
\text { neighbourhood networks, or } \\
\text { customers and suppliers with } \\
\text { good social reputation }\end{array}$ \\
\hline & & $\begin{array}{l}17 . \\
\text { Transparency }\end{array}$ & $\begin{array}{l}\text { External reporting indicators } \\
\text { such as publicly available } \\
\text { annual financial statements or } \\
\text { sustainability reports }\end{array}$ \\
\hline \multirow{4}{*}{ The loan } & \multirow{3}{*}{ Financial criteria } & 18. Profitability & $\begin{array}{l}\text { Net Present Value of the } \\
\text { project based on hypotheses on } \\
\text { income and expenses evolution }\end{array}$ \\
\hline & & 19. Risks & $\begin{array}{l}\text { Risks associated to the project } \\
\text { such as brain drain, harmful } \\
\text { lobbying or reputation fall }\end{array}$ \\
\hline & & 20. Liquidity & $\begin{array}{l}\text { How and when the investment } \\
\text { will be recovered, measured } \\
\text { by the pay back }\end{array}$ \\
\hline & Social criteria & $\begin{array}{l}\text { 21. Impact on } \\
\text { employment }\end{array}$ & $\begin{array}{l}\text { Number of jobs created, and } \\
\text { SROI calculated on the basis } \\
\text { on applicant's average annual } \\
\text { wages, taxes and social } \\
\text { security contributions and } \\
\text { unemployment benefits saved }\end{array}$ \\
\hline
\end{tabular}




\begin{tabular}{|c|c|c|c|}
\hline \multirow[t]{6}{*}{ Branch } & \multirow[t]{6}{*}{ Criterion } & & Indicators examples \\
\hline & & $\begin{array}{l}\text { 22. Impact on } \\
\text { education }\end{array}$ & $\begin{array}{l}\text { Number of people that will } \\
\text { improve their educational } \\
\text { levels and SROI calculated on } \\
\text { the basis on the costs of } \\
\text { training courses within the } \\
\text { company }\end{array}$ \\
\hline & & $\begin{array}{l}\text { 23. Diversity } \\
\text { and equal } \\
\text { opportunities }\end{array}$ & $\begin{array}{l}\text { Percentages of insertion jobs, } \\
\text { ethnic minority staff or } \\
\text { handicapped employees to be } \\
\text { hired }\end{array}$ \\
\hline & & $\begin{array}{l}\text { 24. Community } \\
\text { outreach }\end{array}$ & $\begin{array}{l}\text { How the project increases } \\
\text { community income or reduces } \\
\text { misbehaviour among young } \\
\text { people, measured by the staff } \\
\text { volunteer time devoted to the } \\
\text { community, or the purchases } \\
\text { percentage made to suppliers } \\
\text { in the neighbourhood }\end{array}$ \\
\hline & & $\begin{array}{l}\text { 25. Impact on } \\
\text { health }\end{array}$ & $\begin{array}{l}\text { How the project promotes } \\
\text { healthy diet or reduces mental } \\
\text { disorders, measured by the } \\
\text { reduction of sick leave and } \\
\text { savings in medicaments }\end{array}$ \\
\hline & & $\begin{array}{l}\text { 26. Impact on } \\
\text { the environment }\end{array}$ & $\begin{array}{l}\text { Tonnes of CO2 saved by } \\
\text { reducing emissions and tonnes } \\
\text { of waste saved by recycling }\end{array}$ \\
\hline
\end{tabular}

The first branch (history) aims at analysing the past repayment behaviour of the applicant. For this reason, three criteria were included: (1) history of payments to the cooperative, (2) history with financial institutions and public sector and (3) history of payments to suppliers. Some associated indicators are related to timely payments, write-offs or lawsuits. They are obtained from internal sources or public records from credit reference agencies.

The second branch (present) tries to analyse the financial health of the applicant, as well as its intangible assets. The first four criteria analyse (4) business growth, (5) profitability, efficiency and productivity, (6) short-term liquidity and (7) long-term solvency. Indicators are financial ratios extracted form the last 5 year's annual reports. The second group of criteria analyses intangible assets according to the three categories suggested by Sveiby (1997) in his intangible assets monitor: human capital, internal assets and external assets. See also Grace and 
Tang (2009) for a model to evaluate intangible assets with AHP. Human capital criteria aim at analysing (8) the expertise of the board, (9) the skills of the staff and (10) the company's labour responsibility. Internal assets criteria assess (11) the coherence of vision and values, (12) the quality of the applicant processes and technology and (13) its degree of innovation. External assets criteria assess (14) customers' value, (15) the applicant's social image, (16) its commitment with the community and (17) the applicant's transparency levels.

The third branch (future) analyses the project to be financed, from financial and social points of view. The financial criteria branch tries to use MCDM for financial project selection. Steuer and Na (2003) review 256 papers on the application of the techniques of multi-criteria decision making (MCDM) to problems and issues in Finance. They affirm that despite the many simplifying single criterion, much of the world of Finance resides fundamentally within an environment of multiple conflicting objectives. Graham and Harvey (2002) surveyed managers on the financial criteria used to evaluate projects. Most of them consider a minimum of three financial criteria: (18) return, (19) risk and (20) liquidity; indeed included in the model. Profitability is assessed in terms of discounted cash flows to calculate the net present value and other indicators. Risk is assessed by means of a risk matrix, which combines the occurrence probability and the impact of typical risks in business analysis. One of them is the reputational risk, which has a clear impact in social companies, Schaefer (2004). Finally, liquidity takes common indicators, such as the pay back.

The inclusion of risk in project selection is a complex issue. There is no consensus on how firms should evaluate risky cash flows and much research remains to be done, Smith and von Winterfeldt (2004). The common practice is adjusting the capitalization rates applied to the NPV of the projected cash flows. For the perceived riskiness of the flows: the greater the risk, the higher the discount rate, Lewellen (1977). Following this approach, care of not double counting the risk has to be taken: firstly in the discount rate and then by representing the NPV as a probability distribution. For this reason, we choose to discount cash flows at the risk-free rate. Coop57 found it difficult to justify the use of different discount rates to different projects, because their members could consider it arbitrary. By contrast, they found it more feasible to include a risk matrix in the spreadsheet, because it allowed identifying clearly the threats and then scoring them. Another way of dealing with risk issues is proposing states of 
nature and their probabilities, calculating the expected utility of the NPV. If the information about the states of nature and their probabilities was available, a good model of the investment could be built. Decision making under uncertainty arises when the information about the probability distributions is not available. In this case, it is advisable to use alternative decision techniques using criteria robust to uncertainty of probability of outcomes, such as maximin, minimax, Hurwicz or LaPlace, see Tsang et al. (2007).

To assess the social impact of the project, we adapted the Millennium Development Goals, the GRI framework and the GRI Financial Services Sector Supplement, GRI (2011). The six social criteria are (21) the impact on job creation, (22) the impact on education, (23) the impact on diversity and equal opportunities, (24) community outreach, (25) the impact on health, and finally (26), the impact on the environment. All of these have associated indicators taken from GRI (2011). In the case of employment, education, community outreach and environmental criteria, quantitative indicators are calculated using the SROI approach. For example, to assess the social impact of job creation, first, the number of new jobs if the loan was finally approved was estimated for the next years; second, outcomes were mapped, such as the value of the wages, the taxes, social security contributions, and the unemployment benefits saved. These values were taken form the Spanish Statistics Institute. Then, quantitative data are obtained by calculating the present value of the outcome applying the appropriate discount rate.

Notice that the model was designed to be comprehensive and non-redundant. Comprehensiveness means that any aspect that could be of interest in the credit score process can fit into the model. Non-redundancy means that any of the aspects would fit only in one of the criteria. This is because one aspect either belongs to the present, the past or the future, either is tangible or intangible and either is financial or social. The same pattern has led the selection of the criteria in each branch.

\section{Prioritization}

In the second stage, members of the cooperative board expressed their preferences individually by means of pairwise comparisons among the 26 proposed criteria. To this end, they were asked for their preferences in a loan 
application, for example, whether they preferred impact on employment or impact on education. They were also asked on their degree of preference. For example, they stated that "the impact on employment is extremely preferred over the impact on education”. These individual preferences were aggregated by means of the geometric mean, and after applying the AHP algorithm, the cooperative preferences were set. According to Aczel and Saaty (1983), the geometric mean is the appropriate rule for combining judgments since it preserves the reciprocal property of the judgments matrix. No inconsistency arose from the preferences of the board members. Figure 2 displays these preferences in the form of weights. Preferences reflect the mission/vision of the cooperative and what matters in giving loans. So unless the board would like to update them, they are going to remain unchanged. Figure 2 reveals that, for board members, the present of the company (50.2\%) is more important than the payment history (29.4\%) or the project (20.4\%); the information provided from accounting statements is more valued (59.05\%) than the intangible assets information (40.95\%); and the social impact of the project (67.53\%) weighs more than financial projections (32.47\%).

Fig. 2

Screenshot of the decision support system, showing the balanced scorecard, which includes board's weights and scores

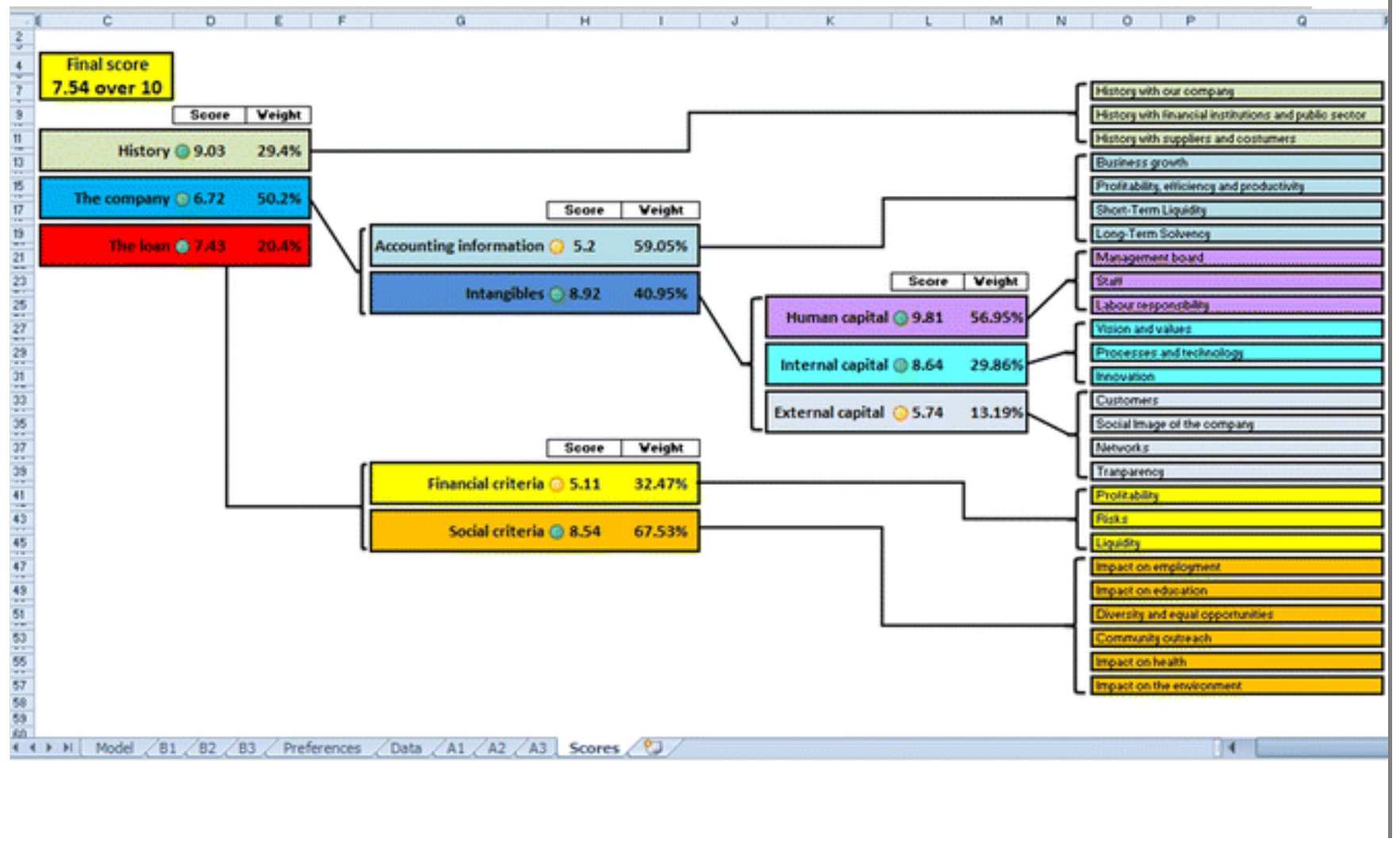




\section{Assessment}

In the third stage, the value of the applicant indicators was introduced in the system to enable the assessment of the different criteria. Members of the social committee, as well as members of the financial committee, equivalent to bank credit analysts, scored each criterion based on the indicators' values using a 7-point Likert scale, ranging from excellent to extremely low. For example, a member of the financial committee, after analysing sales and profit growth ratios scored as "low" the criterion "business growth". The same procedure was followed in the social assessment. Social committee members, after analysing the number of jobs created, the percentage of handicapped staff, and the SROI quantitative data, assigned an "excellent" to the impact on employment. After several analysts evaluated the loan application, their assessments were aggregated using the geometric mean.

\section{Synthesis}

Finally, after multiplying the board's preferences with analysts' assessments, partial scores were obtained for each criterion and each branch. The final score is obtained from these partial scores. This final score is important, but the 36 partial scores related to criteria and branches allow identifying the strengths and weaknesses of the application. These are shown as traffic light icons in the balanced scorecard of Fig. 2 .

\section{Assessment of the Loan Application Presented by the Bike Courier Company}

La Veloz is a bicycle messenger company that is organized in a cooperative legal form. Its values are based on equitable wages, the use of sustainable and environmentally friendly means of production like bicycles and a commitment to community. In fact, the company chose to be based in an impoverished neighbourhood. La Veloz has been a member of Coop57 since 2005. It has previously asked for five loans to expand its business. The current situation of crisis has led its clients to delay their payments, and banks have also tightened the conditions for loan approval. This time, they asked for a 60,000 € loan to be repaid in 5 years with monthly instalments. The assessments of the different criteria and indicators are explained below.

\section{History It should have the same size as "The Company:}




\section{Accounting Information" below}

Given the long-term relationship that links La Veloz to Coop57, its credit history was well known and positive. To assess the history with financial institutions and the public sector, records from credit reference agencies were searched. No engagement in lawsuits and no presence in debtors' lists were detected. The information on La Veloz from suppliers was positive. The partial score is very high: 9.03 over 10 in Fig. 2 .

\section{The Company: Accounting Information}

The economic crisis hit the company which is reflected in business growth financial ratios. Despite the fall in sales, jobs have been maintained, which has negatively affected productivity ratios. Finally, solvency ratios reflect the mismatch between collections and payments, which led the company to ask for the loan. The partial score is 5.2 over 10 .

\section{The Company: Intangibles}

Among all the indicators, the following can be highlighted: the awards received by managers as well as their experience, the high educational levels of the staff, the lack of absenteeism from work and the low level of wage inequality. All indicators of vision and values were positive and coherent with the daily performance of the company. Some weaknesses arose in innovation, given the low level of $\mathrm{R}+\mathrm{D}$ investment. The management systems were acceptable, presenting an Enterprise Resource Planning, monthly budgets and cash flow forecasts. Customers' loyalty indicators were positive; the company displayed a remarkable presence in mass media and also actively participated in community networks. By contrast, the company did not audit its accounts, did not present sustainability reports, and its webpage did not display updated corporate information. The partial score is 9.81 for human capital, 8.64 for internal capital and 5.74 for external capital, which, after weighing, gives an 8.92 score.

\section{The Project: Financial Criteria}

The Net Present Value was positive, but low. The risk level of the applicant was low, given the probability and impact of each risk analysed. The possibility of new competitors entering the market and a scenario of high interest rates should be watched. Loan securitization was not possible, which negatively affected the 
liquidity criterion. The partial score is 5.11 over 10 .

\section{The Project: Social Criteria}

The project hardly has an impact on education, nor on health or on equal opportunities. The impact on employment is noticeable. It was assessed through SROI using the following data from the Spanish Statistical Institute: average wages in the sector, average tax burden in Spain and freed-up resources associated with unemployment benefits.

The company is based on a street of an impoverished neighbourhood. Using SROI, the positive impact of having the company there can be quantified by considering the wages and expenses saved by the city council in security. Local police surveillance costs were taken as a proxy of the security feeling in the neighbourhood due to bike messengers passing by.

Two environmental aspects were assessed through SROI: savings in $\mathrm{CO}_{2}$ from using bikes instead of vehicles based on fuel consumption and savings in waste treatment due to recycling practices. As a proxy of the first outcome, the average price of $\mathrm{CO}_{2}$ emissions by the $\mathrm{CO}_{2}$ trading market was taken. Using bikes for delivery, $50 \mathrm{CO}_{2}$ tonnes were saved annually. As a proxy of the second outcome, the estimated cost per tonne of waste processed was taken, getting data from the regional government. The recycling activity of the company saved 0.5 tonnes of waste.

The final score of the social impact of the project is 8.54 over 10. Quantifying the social impact through the SROI technique has shed light on interesting issues. Contrary to what was expected, environmental benefits of the bike courier activity were low in monetary terms, because the average price of $\mathrm{CO}^{2} \mathrm{CO}_{2}$ emissions using bikes is $16,3916.39 €$ per tonne, and the estimated cost of waste processed is 61,6861.68 $€$ per tonne. The community outreach of the project was much more relevant in monetary terms, as well as its impact on employment, just considering that average annual wages in the sector are 14,400 € and annual savings in unemployment benefits are 7,014 €.

The scores of the three main branches are 9.03 for history, 6.72 for the situation of the company and 7.43 for its future project. After applying their weights, a final score of 7.54 over 10 is reached. Because the AHP absolute measurement 
mode was used, the model provides a rating for each application, so it is possible to fix a threshold. The cooperative requires soundness in both financial and social aspects, which in the model correspond to obtaining a minimum 5 over 10 . Agreed loan applications are ranked and funded according to the funds available. Given all the above reasons, the applicant qualifies for the loan, with some recommendations to improve some aspects of the company.

A possible improvement for the model is to obtain the probability of default (PD) from a sample of defaulted and non-defaulted loans. This is in line with the requirements of Basel Accords (BIS 2004) for banks. Although Coop57 is not under the central bank supervision, it would be desirable to develop a sound statistical model. This would replace the two first branches by the probability of default, using the logistic regression technique. This was not possible, due to lack of data, especially for defaulted loans. The delinquency level for Coop57 does not reach the $1 \%$ of the loan portfolio. With such a delinquency level, hundreds of loans should need to be screened to find some defaulted ones; and Coop57 does not currently have such database. When Coop57 will grow and will have more data available, the criteria 1-17 would be very adequate to design a PD model. It could also be useful for other entities, such as large ethical banks, which have more available information.

AQ3

\section{Conclusions}

Many different entities perform socially responsible lending: ethical banks, social entities that collect savings and microfinance institutions are the most relevant. They usually employ a credit score system that relies on financial aspects and a social or ethical filter that rejects non-suitable applications on the basis of a negative impact on the environment or vetted sectors such as tobacco or gambling. This paper proposes the use of well-formalized social credit score systems. This means that social aspects of the credit application should be evaluated with the same meticulousness as financial aspects are analysed. To this end, some social impact assessment (SIA) methodologies could be useful.

A model for social credit score has been proposed. It contain three main aspects: (1) applicant credit history, (2) the present situation of the company, evaluated from accounting information, as well as from intangible assets information and 
(3) the project to be financed, evaluated from financial and social points of view. The model proposes the assessment of the following social aspects: impact on employment, impact on education, diversity and equal opportunities, community outreach, impact on health and impact on the environment. These criteria are reflected in a good number of measurable indicators. The social return on investment (SROI) is one of them, which is very appropriate for a credit score due to its quantitative nature.

Each funder has a different mission: for example, some prefer environmental protection and some others aim at women empowerment. A possible way of including the preferences of the institution in the social credit score is using Multi-criteria decision makingMulti-Criteria Decision Making (MCDM). Through MCDM, the knowledge of the financial analysts as well as SIA analysts has been introduced within the decision support system. This way, the social credit score system implements the mission and know-how of the lender.

The model has been applied to a real loan application presented by a social entrepreneur (bike messenger) to a financial services cooperative. The paper illustrates the four stages followed to develop the social credit score system: (1) modelling, (2) prioritization, (3) assessment and (4) synthesis. The model obtains a final score that qualifies the loan application. Beyond score, strengths and weaknesses of the application are identified. In the analysed case, its strengths were its solid credit history and its social assessment in terms of impact on employment and community outreach.

\section{Acknowledgments}

The work reported in this paper was supported by Grant GrantsECO2010-20228 and ECO2013-45568-R of the Spanish Ministry of Education and Science, and the European Regional Development Fund and by grant Ref. S-14 (3) of the Government of Aragon. We are especially grateful to Coop57 Aragon and La Veloz staff for their support in this research.

\section{References}

Aczel, J., \& Saaty, T. L. (1983). Procedures for synthesizing ratio judgments. Journal of Mathematical Psychology, 27(1), 93-102. 
Ambec, S., \& Treich, N. (2007). Roscas as financial agreements to cope with self-control. Journal of Development Economics, 82(1), 120-137.

Appleyard, L. (2011). Community development finance institutions (CDFIs): Geographies of financial inclusion in the US and UK. Geoforum, 42(2), 250-258.

Becker, H. A. (2001). Social impact assessment. European Journal of Operational Research, 128(2), 311-321.

Belton, V., \& Gear, T. (1983). On a short-coming of Saaty's method of analytic hierarchies. Omega, 11, 228-230.

BIS (2004). International Convergence of Capital Measurement and Capital Standards, A Revised Framework, Basel Committee on Banking Supervision, Bank for International Settlements (BIS) Basel, Switzerland.

Bouman, F. J. A. (1995). Rotating and accumulating savings and credit associations: A development perspective. World Development, 23(3), 371-384.

Burdge, R. J. (2003). The practice of social impact assessment. Impact Assessment and Project Appraisal, 21(2), 84-88.

Buttle, M. (2007). I'm not in it for the money: Constructing and mediating ethical reconnections in UK social banking. Geoforum, 38(6), 1076-1088.

CGAP (2011). Measuring changes in client lives through microfinance: Contributions of different approaches. CGAP brief. Consultative Group to Assist the Poorest, World Bank, Washington DC.

Davis, F. D. (1989). Perceived usefulness, perceived ease of use, and user acceptance of information technology. MIS Quarterly, 13(3), 319-340.

Dyer, J. S. (1990). Remarks on the analytic hierarchy process. Management Science, 36, 249-258.

Elkington, J. (1997). Cannibals with forks: The triple bottom line of 21st 
century business. Gabriola Island: New Society Publishers.

Fock, H., Chan, A., \& Yan, D. (2011). Member-organization connection impacts in affinity marketing. Journal of Business Research, 64(7), 672-679.

Forbes, D. (1998). Measuring the unmeasurable. Nonprofit and Voluntary Sector Quarterly, 27(2), 183-202.

Frame, B., \& O’Connor, M. (2011). Integrating valuation and deliberation: the purposes of sustainability assessment. Environmental Science \& Policy, 14(1), $1-10$.

Goddard, J. A., McKillop, D. G., \& Wilson, J. O. S. (2002). The growth of US credit unions. Journal of Banking \& Finance, 26(12), 2327-2356.

Grace, T. R. L., \& Tang, J. Y. H. (2009). Appraising intangible assets from the viewpoint of value drivers. Journal of Business Ethics, 88(4), 679-689.

Graham, J., \& Harvey, C. (2002). How do CFOs make capital budgeting and capital structure decisions? Journal of Applied Corporate Finance, 15(1), 8-23.

GRI (2011). Sustainability reporting guidelines, version 3.1. Global Reporting Initiative. Accessed June 24, 2011, from www.globalreporting.org.

Gutiérrez-Nieto, B., Serrano-Cinca, C., \& Mar-Molinero, C. (2009). Social efficiency in microfinance institutions. Journal of the Operational Research Society, 60(1), 104-119.

Harris, J. D., Sapienza, H. J., \& Bowie, N. E. (2009). Ethics and entrepreneurship. Journal of Business Venturing, 24(5), 407-418.

IAIA (2011). What is impact assessment? International Association for Impact Assessment. Accessed June 24, 2011, from http://www.iaia.org /publicdocuments/special-publications/What\%20is\%20IA_web.pdf.

Johnson, S. A., \& Sarkar, S. K. (1996). The valuation effects of the 1977 community reinvestment act and its enforcement. Journal of Banking \& 
Finance, 20(5), 783-803.

Keeney, R. L., \& Raiffa, H. (1976). Decisions with multiple objectives: Preferences and value tradeoffs. New York: Wiley.

Lewellen, W. G. (1977). Some observations on risk-adjusted discount rates. The Journal of Finance, 32(4), 1331-1337.

Millet, I. (1998). Ethical decision making using the analytic hierarchy process. Journal of Business Ethics, 17(11), 1197-1204.

Moneva, J. M., Archel, P., \& Correa, C. (2006). GRI and the camouflaging of corporate unsustainability. Accounting Forum, 30(2), 121-137.

Morduch, J. (1999). The microfinance promise. Journal of Economic Literature, 37(4), 1569-1614.

Peters, M., \& Zelewski, S. (2008). Pitfalls in the application of analytic hierarchy process to performance measurement. Management Decision, 46(7), 1039-1051.

REDF. (2001). SROI methodology: A social return on investment, analyzing the value of social purpose enterprise within a social return on investment framework. San Francisco: Roberts Enterprise Development Fund, The Roberts Foundation.

Ruf, B. M., Muralidhar, K., \& Paul, K. (1998). The development of a systematic, aggregate measure of corporate social performance. Journal of Management, 24(1), 119-133.

Saaty, T. L. (1980). The analytic hierarchy process. New York: McGraw-Hill.

Schaefer, H. (2004). Ethical investment of German non-profit organizations: Conceptual outline and empirical results. Business Ethics: A European Review, 13(4), 269-286.

Schreiner, M. (2002). Scoring: The next breakthrough in microfinance? Occasional Paper 7. Consultative group to assist the poorest (CGAP). 
Washington DC.

Searcy, C. (2012). Corporate sustainability performance measurement systems: A review and research agenda. Journal of Business Ethics, 107, 239-253.

Smith, J. E., \& von Winterfeldt, D. (2004). Decision analysis in management science. Management Science, 50(5), 561-574.

Stein, E. W., \& Ahmad, N. (2009). Using the analytical hierarchy process (AHP) to construct a measure of the magnitude of consequences component of moral intensity. Journal of Business Ethics, 89(3), 391-407.

Steuer, R. E., \& Na, P. (2003). Multiple criteria decision making combined with finance: A categorized bibliographic study. European Journal of Operational Research, 150(3), 496-515.

Sveiby, K. (1997). The new organizational wealth: managing and measuring knowledge-based assets. New York, NY: Berrett-Koehler.

Triodos Bank (2011). Triodos Bank’s approach to lending. Accessed June 24, 2011 from http://www.triodos.com/downloads/lending-criteria.pdf.

Tsai, W.-H., \& Chou, W.-C. (2009). Selecting management systems for sustainable development in SMEs: A novel hybrid model based on DEMATEL, ANP, and ZOGP. Expert Systems with Applications, 36(2), 1444-1458.

Tsang, K. H., Samsatli, N. J., \& Shah, N. (2007). Capacity investment planning for multiple vaccines under uncertainty: 2: Financial risk analysis. Food and Bioproducts Processing, 85(2), 129-140.

Vanclay, F. (2010). The triple bottom line and impact assessment: How do TBL, EIA, SIA, SEA and EMS relate to each other? In W. R. Sheate (Ed.), Tools, techniques and approaches for sustainability (pp. 101-124). Singapore: World Scientific Publishing. 
Yurdakul, M., \& Iç, Y. T. (2004). AHP approach in the credit evaluation of the manufacturing firms in Turkey. International Journal of Production Economics, 88(3), 269-289.

Zahra, S. A., Gedajlovic, E., Neubaum, D. O., \& Shulman, J. M. (2009). A typology of social entrepreneurs: Motives, search processes and ethical challenges. Journal of Business Venturing, 24(5), 519-532. 